\title{
Nutrient Intake, Fermentation, Digestibility and Growth Performance of Barbarin Lamb Supplemented with Sweet Lupin
}

\author{
H Arfaoui ${ }^{2}$, H Ben Salem ${ }^{1}$, S Nasri ${ }^{1}$ and M Mezni ${ }^{1}$, S Abidii ${ }^{1 *}$ \\ ${ }^{1}$ Institut National de la Recherche Agronomique de Tunisie (INRAT), Université de Carthage, Laboratoire des Productions Animale et Fourragère, Tunisia \\ ${ }^{2}$ Institut National Agronomique de Tunis, Université de Carthage, Tunisia
}

*Corresponding author: Sourour Abidi, Institut National de la Recherche Agronomique de Tunisie (INRAT), Université de Carthage, Laboratoire des Productions Animale et Fourragère, rue Hédi Karray, EL-Manzah, Tunisia.

Received Date: February 25, 2020

Published Date: March 02, 2020

\begin{abstract}
This study aims to evaluate the effect of white lupine seeds as a substitute for soybean meal in the diets of Twenty-four 6 and a half monthold Barbarine lambs (average initial weight $23 \mathrm{~kg}$ ) were divided into three equal groups. Three types of concentrates, the first two of which were iso-nitrogenous, were formulated as follows: CC1 containing 75\% barley, 22.5\% soybean meal and 2.5\%mineral and vitamin supplement; CC2 containing lupine as a substitute for soybeans; and CC3 containing only barley and CMV (This is the concentrated 1 devoid of soybean meal). In addition to the hay that was distributed ad libitum, animals assigned to the first and the second group received daily, $500 \mathrm{~g}$ of concentrate 1 and $500 \mathrm{~g}$ of concentrate 2 , respectively. Those assigned to the third one received alternately concentrate 2 (day1) and concentrate 3 (day2). Experiment period was divided in a growth period ( 80 days) followed by a digestible period ( 10 days). Diet had no significant effect on total dry matter and water intakes, average daily gain, diet digestibility and microbial synthesis $(P>0.05)$. For the nitrogen balance, the animals showed different retained nitrogen level $(\mathrm{P}<0.05)$. Fermentation parameters were not affected by protein source. However, only the number of protozoa was influenced by the day of fluid collection $(\mathrm{P}<0.05)$. It can be concluded that lupine grains can substitute safely soybean meal in diets of Barbarine lambs.
\end{abstract}

Keywords: Soybean meal; Lupine; Barbarin lambs; Fermentation; Digestibility; Average daily gain

\section{Introduction}

In Tunisia, particularly in the arid and semi-arid zones, climatic conditions have caused the degradation of rangelands leading to a chronic forage deficit and a nutritional imbalance in animals, particularly in sheep and goats. Thus, energy and / or nitrogen supplementation has become essential to maintain these animals and ensure the expected performance. For this reason, Tunisia has resorted to the import of raw materials including soybean meal, barley and corn [1]. However, fluctuations in their prices on the world market are negatively affecting animal nutrition industry. Our country imports annually, over 300,000 tons of soybean meal at a price of $1.2 \mathrm{dt} / \mathrm{kg}$ [2]. Similarly, these imported raw materials are unstably available on the Tunisian market which can affect the profitability of farms and alter the sustainability of animal production sector in Tunisia. As a result, several attempts to replace these foods, including soybean meal, have been considered by researchers. Protein crops (Lupine, faba beans and peas) are good alternatives to soybean meal because of their high crude protein content. However, despite their good nutritional quality, their use in animal nutrition is currently limited due to the presence of anti-nutritional factors (Faba bean tannins, lupine alkaloids) and their fluctuating availability on the market (limited forage legume crops). Thus, the main objective of this study is the evaluation of the substitution effect of soybean meal by sweet lupine on the ingestion, digestion, growth and meat quality in Barbarine lambs.

\section{Materials and Methods}

\section{Animals}

Twenty-four six-month-old Barbarine lambs were selected. The initial live weight averaged $23 \mathrm{~kg}$. These animals were transported to INRAT headquarters. They were acclimated for 4 
days to new housing conditions. Lambs were weighed than divided into three equal groups. All animals received oat hay ad libitum and concentrate. the first group received CC1 containing 75\% barley, $22.5 \%$ soybean meal and 2.5\% CMV, whereas the second received CC2 containing lupine as a substitute for soybeans in term of $\mathrm{CP}$ to be iso-nitrogenous with $\mathrm{CC} 1$. The third group received intermittently CC2 and CC3 which contain only barley and CMV. Animals have undergone a growth period (80 days) followed by a digestible period (10 days).

\section{Sampling}

During growth period, average daily growth was assessed through weighing animals biweekly. At digestible period, lambs were housed individually in metabolic cages and were allowed three days for acclimatization to new conditions. Animals received weighed amounts of corresponding feed. A 7-day faecal collection period started on the following day. After weighing the amounts of fresh feed, refusals and faeces, samples of each were taken daily. Part of each sample was used for DM determination and the other part (20\% of the weight of the fresh refusals and faeces) was stored at $4{ }^{\circ} \mathrm{C}$ for hay and concentrates or at $-5{ }^{\circ} \mathrm{C}$ for faeces. Urine was collected in plastic recipients containing $100 \mathrm{ml}$ of a $10 \%$ sulphuric acid solution ( $\mathrm{v} / \mathrm{v}$ ) to maintain $\mathrm{pH}$ below 3. After weighing, an aliquot (10\%) corresponding to each animal was taken and frozen $\left(-20{ }^{\circ} \mathrm{C}\right)$. In the last day, pooled samples of individual feed refusal, and faeces were dried at $50{ }^{\circ} \mathrm{C}$; ground through $1 \mathrm{~mm}$ screen then stored pending analysis. Pooled samples of urine were stored in the freezer $\left(-20^{\circ} \mathrm{C}\right)$ until analyzed. Rumen fluid was taken in two consecutive days to measure $\mathrm{pH}$ and ammonia content and to determine protozoa number.

\section{Analyses}

Feed, refusals and faeces samples were analyzed for dry matter (DM), ash and crude protein according to AOAC [3]. They were also analysed for (NDF, ADF and ADL) [4]. Urine was analyzed for Kjeldahl nitrogen [3] and allantoin concentrations measured using a colorimetric method. Urinary excretion of allantoin (Y, mmol/d) was used to calculate microbial purines absorbed (X, mmol/d [5]. Rumen fluid samples were analyzed for NH3-N [6].

\section{Statistical analysis}

The statistical analysis of the results was performed using an analysis of variance according to the model: Yijk $=\mu+A i+\varepsilon i$.

In which $\mu=$ arithmetic mean; $\mathrm{Ai}=$ the effect of diet ( $\mathrm{i}=1,2$ or 3 ) and $\varepsilon i$ is the residual experimental error. Data were analyzed using the ANOVA procedure. All statistical analyses were carried out using the GLM (general linear model) procedures of SAS Package (1987). Differences between the means of all the analyses were analyzed using the LSMEANS procedure.

\section{Results and Discussion}

Table 1: Chemical composition of the experimental feeds (g/kg DM).

\begin{tabular}{|c|c|c|c|c|}
\hline & Oat Hay & Soyabean Meal & Lupine & Barely \\
\hline DM & 929 & 903 & 903 & 896 \\
\hline $\mathrm{OM}$ & 915 & 932 & 967 & 974 \\
\hline $\mathrm{CP}$ & 77.6 & 480 & 329 & 110 \\
\hline $\mathrm{NDF}$ & 673 & 172 & 270 & 489 \\
\hline $\mathrm{ADF}$ & 404.3 & 52.9 & 151.6 & 102.2 \\
\hline $\mathrm{ADL}$ & 62.5 & 3.75 & 8.63 & 25.9 \\
\hline
\end{tabular}

Nutrient contents of feeds are presented in Table 1. Soyabean meal is greater in $\mathrm{CP}$ than lupine, while the opposite trend was observed for NDF, ADF and ADL.

Diets intake and digestibility are shown in Table 2. Results revealed that the nature of the additional protein source did not affect feed intake ( $P>0.05)$, which corroborates with results reported by El Maadoudi [7] and El Maadoudi and El Housni [8]. The level of hay ingestion considered similar between the three groups reminds us of the result reported by Ephrem et al. [9]. This could be explained by the importance of the nutritional quality of protein sources and the tolerance of sheep to lupine alkaloids. Nevertheless, our results are contradictory to those reported by Lestingi et al. $[10,11]$ by testing the replacement of peas and faba beans. In addition, proteins source did not reveal a significant effect on digestibility of MS, MO, MAT and NDF (P>0.05). The amount of DCPi was significantly affected $(P=0.0003)$. Purroy et al [12] did observed significant differences in DM, OM, CP and fiber digestibility's by replacing soybean meal with lupine seed in lambs. The incorporation of lupine into different quantities improved digestibility's of DM, OM and cellulose without affecting those of NDF and ADF [13]. Lupine had no significant effect on their average daily gain (ADG). This result agrees with those of many trials carried out on the replacement of protein seeds by lupine which revealed comparable digestive uses between diets $[9,11,14,15]$. Moreover, Facciolongo et al. [16] found that supplementation with soybean meal and lupine induced similar ADG, while Lestingi et al. [10] showed low weight gain in animals fed lupine diet compared to those which consumed faba beans. We note that although the 3rd group received half of the quantity of lupine consumed by the 2 nd one, the corresponding lambs were able to have similar and even better ADG than the others. This leads us to think about the concept of food efficiency. It seems that these animals were able to optimize their efficiency to transform food resources into meat to reach same weight as the others. The nitrogen balance and microbial synthesis 
are shown in Table 3. It appears that all animals had positive balances. However, a significant variation in the amount of nitrogen intake and retention was observed in the 3rd group in comparison with the two others. This difference is explained by the variation of the ingested quantity of the concentrate. On the other hand, by correcting the retained nitrogen to the nitrogen intake, the nitrogen balance was similar for all diets, which confirms that animals had the same nitrogen use efficiency. Moreover, similar CP digestibility reinforces this finding.

Table 2: Effect of supplementation of lupine on intake, apparent digestibility of diets and daily gain in lambs.

\begin{tabular}{|c|c|c|c|c|c|}
\hline & \multicolumn{3}{|c|}{ Diets } & \multirow{2}{*}{ ESM } & \multirow{2}{*}{ P-Value } \\
\hline & 1 & 2 & 3 & & \\
\hline \multicolumn{6}{|c|}{ DM Intake (g/Kg BW0.75) } \\
\hline Hay & 50,9 & 50,5 & 53,0 & 2,56 & 0,7639 \\
\hline Diet & 84,1 & 85,0 & 82,3 & 2,73 & 0,7695 \\
\hline \multicolumn{6}{|c|}{ Digestibility (\%) } \\
\hline DM & 68,9 & 68,4 & 68,8 & 1,02 & 0,9294 \\
\hline $\mathrm{OM}$ & 71,0 & 70,4 & 70,9 & 0,98 & 0,8896 \\
\hline $\mathrm{CP}$ & 70,5 & 70,7 & 68,9 & 1,11 & 0,4831 \\
\hline NDF & 67,2 & 65,5 & 65,2 & 1,19 & 0,4592 \\
\hline \multicolumn{6}{|c|}{ Intake (g/Kg BW0.75) } \\
\hline DOM & 55,6 & 55,7 & 54,0 & 1,68 & 0,7227 \\
\hline DCP & $7,96^{\mathrm{a}}$ & $8,23^{\mathrm{a}}$ & $6,84^{\mathrm{b}}$ & 0,20 & 0,0003 \\
\hline \multicolumn{6}{|c|}{ Water consomption } \\
\hline 1/Kg BW0.75 & 0,27 & 0,29 & 0,25 & 0,02 & 0,1617 \\
\hline $\begin{array}{l}\text { Average daily gain, g/ } \\
\text { day }\end{array}$ & 99.91 & 82.14 & 101.3 & 6.39 & 0.0835 \\
\hline
\end{tabular}

a,b Means in the same line with different superscripts are significantly different $(P<0.05)$. SEM: Standard error of the mean. DM: Dry matter, OM: organic matter, CP: crude protein, NDF: neutral detergent fiber, DOM: Digestible organic matter, DCP: digestible crude protein.

Table 3: Effect of supplementation of lupine on nitrogen balance and microbial $\mathrm{N}$ supply in lambs.

\begin{tabular}{|c|c|c|c|c|c|}
\hline & \multicolumn{3}{|c|}{ Diets } & \multirow{2}{*}{ ES } & \multirow{2}{*}{$\operatorname{Pr}$} \\
\hline & 1 & 2 & 3 & & \\
\hline $\begin{array}{l}\text { Nitrogen intake }(\mathrm{Ni}), \\
\mathrm{g} / \mathrm{d}\end{array}$ & $23,10^{\mathrm{a}}$ & $23,02^{\mathrm{a}}$ & $20,26^{\mathrm{b}}$ & 0,42 & 0,0001 \\
\hline Fecal N, g/d & 7,43 & 7,37 & 6,99 & 0,39 & 0,6875 \\
\hline Urinary N, g/d & 4,18 & 4,16 & 3,71 & 0,49 & 0,7475 \\
\hline Retained N,g/d & $11,48^{\mathrm{a}}$ & $11,50^{\mathrm{a}}$ & $9,56^{\mathrm{b}}$ & 0,49 & 0,0176 \\
\hline Retained N, \% Ni & 49,69 & 49,90 & 47,61 & 2,41 & 0,7636 \\
\hline Allantoïne, mg/Kg0.75 & 7.75 & 7.89 & 8.74 & 1.17 & 0.817 \\
\hline $\begin{array}{l}\text { Xanthine + hypoxan- } \\
\text { thine, mmol/day }\end{array}$ & 4.14 & 4.02 & 4.19 & 0.11 & 0.4953 \\
\hline Total purine, $\mathrm{mmol} / \mathrm{d}$ & 13.34 & 13.16 & 14 & 0.69 & 0.6668 \\
\hline Microbien N, g/d & 9.7 & 9.57 & 10.18 & 0.5 & 0.666 \\
\hline
\end{tabular}

a,b Means in the same line with different superscripts are significantly different $(P<0.05)$. SEM: Standard error of the mean.

The total amount of purine and the amount of microbial nitrogen were not influenced by the source of supplemented proteins $(\mathrm{P}>0.05)$, which is consistent with the lack of effect on the CP digestibility. In accordance with our results, Yu et al. [17] found no significant differences between purine and microbial nitrogen concentrations in lambs supplemented or not with blue lupine or faba beans.

Table 4 presents the different fermentation parameters. Our study showed that the average $\mathrm{pH}$ of rumen juice was affected by the diet $(\mathrm{P}<0.05)$. $\mathrm{pH}$ corresponding to the 2nd group (6.25) exceeded significantly that of the 1st group (6.07), but no significant difference was detected between $\mathrm{pH}$ corresponding to the 3rd group (6.13) and the others. Brand et al. [18] reported pH values ranged between 6.4 and 6.3 in castrated rams fed a lupine diet. Rumen ammonia level was affected only by diet (P > 0.05). The highest concentration was observed in daily lupine fed lambs (23.9 mg / dl). White et al. (2002) found that ruminal ammonia concentration was higher with lupine incorporation rate of $70 \%$ 
than with 35\%, which corroborates the high ammonia level in animals receiving lupine daily and the low one in animals receiving lupine intermittently. Protozoa enumeration revealed a significant difference between diets. Animals belonging to the 2nd group had the highest number $(15.3 * 105 / \mathrm{ml})$ whereas those of the 3rd group had the lowest one $(11.7 * 105 / \mathrm{ml})$. This could be explained by the corresponding ammonia concentrations in the rumen since a large population of protozoa is generally associated with a high concentration of ammonia in the rumen $[19,20]$.

Table 4: Effect of supplementation of lupine on nitrogen balance and microbial $\mathrm{N}$ supply in lambs.

\begin{tabular}{|c|c|c|c|c|c|c|c|c|c|c|}
\hline & \multicolumn{2}{|c|}{ Day } & \multicolumn{3}{|c|}{ Diets1 } & \multicolumn{2}{|c|}{ SEM } & \multicolumn{3}{|c|}{ P-Value } \\
\hline & 1 & 2 & 1 & 2 & 3 & Day & Diet & Day & Diet & Day* Diet \\
\hline $\mathrm{pH}$ & 6.1 & 6.2 & $6.1^{\mathrm{a}}$ & $6.2^{\mathrm{b}}$ & $6.1 \mathrm{a}^{\mathrm{b}}$ & 0.02 & 0.03 & 0.114 & 0.001 & 0.66 \\
\hline Protozoaire & 12.4 & 15.1 & $14.4^{\mathrm{ab}}$ & $15.3^{\mathrm{a}}$ & $11.7^{\mathrm{b}}$ & 0.67 & 0.82 & 0.005 & 0.008 & 0.955 \\
\hline $\mathrm{NH}_{3}-\mathrm{N}$ & 20.5 & 19.9 & $19.9^{\mathrm{a}}$ & $23.9^{b}$ & $16.8^{\mathrm{a}}$ & 0.79 & 0.97 & 0.587 & $<.001$ & 0.114 \\
\hline
\end{tabular}

\section{Conclusion}

It can be concluded that lupine grains can substitute safely soybean meal in diets of Barbarine lambs. The distribution intermittently of lupine seems to be a double interesting alternative to soybean meal. It decreases lupine quantity and therefore reduce feeding cost.

\section{Acknowledgement}

None.

\section{Conflict of Interest}

No conflict of interest.

\section{References}

1. Ben Salem H (2011) Mutations in sheep food systems in Tunisia and the placement of alternative resources. In: Khlij E (ed.), Ben Hamouda M (ed.), Gabiña D (ed.). Changes in sheep farming systems and prospects for their sustainability. Zaragoza: CIHEAM / IRESA / OEP, Mediterranean Options: Series A, Mediterranean Seminars 97.

2. Bahri A, Rouissi A, Selmi H, Amraoui M, Tayachi L, et al. (2014) Nutritional characterization of some local protein food resources. Tunisia Renc Rech 21.

3. AOAC, Association of Official Analytical Chemists (1984) Official methods of analysis (14 ${ }^{\text {th }}$ ed.). Washington, DC: Association of Official Analytical Chemists.

4. Van Soest PJ, Robertson JB, Lewis BA (1991) Methods for dietary fibre, neutral detergent fiber, and nonstarch polysaccharides in relation to animal nutrition. J. of Dairy Science 74(10): 3583-3597.

5. Chen XB, Gomes MJ (1992) Estimation of Microbial Protein Supply to Sheep and Cattle based on Urinary Excretion of Purine Derivatives. An Overview of the Technical Details. Occasional Publication 1992. International Feed Resources Unit, Rowett Research Institute, Aberdeen, pp. 19.

6. Weatherburn MW (1967) Phenol hypochlorite reaction for determination of ammonia. Anal Chem 39(8): 971-974.

7. El Maadoudi EH (2004) Lupine and horse-bean seeds in diets of growing and fattening sheep. Nutrition and feeding strategies of sheep and goats under harsh climates. Eds. Bensalem, A Nefzaoui, P Morand Fehr, CI EAM/FAO/INRAT, Zaragoza. Dans: Options Méditerranéennes, Série A 59: $249-253$.

8. El Maadoudi EH, El Housni A (2013a) Lupine grains to replace sunflower meal in the ration of growing / fattening lambs. Mediterranean Options A, 108.
9. El Maadoudi EH, El Housni A (2013b) Sweet and bitter lupine grains in rations for growing-fattening sheep. Mediterranean Options A, 108.

10. Lestingi A, Facciolongo AM, De Marzo D, Nicastro F, Toteda F (2015) The use of faba bean and sweet lupin seeds in fattening lamb feed. 2. Effects on meat quality and fatty acid composition. Small Ruminant Research 131: 2-5.

11. Lestingi A, Facciolongo AM, Jambrenghi AC, Ragni M, Toteda F (2016) The use of peas and sweet lupin seeds alone or in association for fattening lambs: Effects on performance, blood parameters and meat quality. Small Ruminant Research 143: 15-23.

12. Purroy A, Surra J, Sebastian I, Mu Òoz F (1989) Use of grain legumes in feed for lamb bait. 1. Bitter Lupine. Agricultural Economic Technical Information 30(84): 51-59.

13. Ephrem N, Tegegne F, Mekuriaw Y, Yeheyis L (2015) Nutrient intake, digestibility and growth performance of Washera lambs supplemented with graded levels of sweet blue lupin (Lupinus angustifolius L.) seed. Small Ruminant Research 130: 101-107.

14. El Otmani S, Ayadi M, Chentouf M (2013) Effect of lupin on growth performance, carcass characteristics and meat quality of growing and fattening kids. In: Ben Salem H (ed.), López Francos A (ed.). Feeding and management strategies to improve livestock productivity, welfare and product quality under climate change. Series A Mediterranean seminars 107: 207-211.

15. Rondia P, Trembloy N, Simon V, Froidmont E (2009) Lupine as an alternative to soy in the feeding of finished grass lambs in sheepfolds. Sheep and Goat sector no. 30.

16. Facciolongo AM, Rubino G, Zarrilli A, Vicenti A, Ragni M, et al. (2014) Alternative protein sources in lamb feeding 1. Effects on productive performances, carcass characteristics and energy and protein metabolism. Progr Nutr 16(2): 105-115.

17. Yu P, Egan AR, Boon Ek L, Leury BJ (2002) Purine derivative excretion and ruminal microbial yield in growing lambs fed raw and dry roasted legume seeds as protein supplements. Animal Feed Science and Technology 95(1-2): 33-48.

18. Brand TS, Franck F, Coetzee J (1999) Kikuyu (Pennisetum clandestinum) pasture for sheep. 2. Production and nutritional status of ewes with or without lupin (Lupinus albus) supplementation. New Zealand Journal of Agricultural Research 42(4): 467-474.

19. Thivend P, Fonty G, Jouany JP, Durand M, Gouet P (1985) The rumen fermenter. Reproduction Nutrition Development 25(4B): 729-753.

20. White CL, Hanbury CD, Young P, Phillips N, Wiese SC, et al. (2002) The nutritional value of Lathyrus cicera and Lupinus angustifolius grain for sheep. Animal Feed Science and Technology 99(1): 45-64. 